\title{
The Role of Strategic Human Resource Management Practice Mediated by Knowledge Management on Service Quality (Study on the Public and Private Hospitals In South Kalimantan, Indonesia)
}

\author{
Basuki, ${ }^{1}$ Armanu Thoyib ${ }^{2}$, Achmad Sudiro $^{3}$, Atim Djazuli $^{4}$ \\ ${ }^{1,2,3,4}$ Faculty of Economic and Business, Brawijaya University Malang, East Java, Indonesia
}

\begin{abstract}
The objective of this research is to empirically examine both direct and indirect relationship of the strategic human resource management practice role on knowledge management, service quality, and organizational performance. The utilized research approach is positivistic paradigm based on the quantitative method. Twenty three 23 public and private hospitals in South Kalimantan (Indonesia) are involved as the unit analysis of this research. There are 115 respondents who work as hospital' managers, physicians, and nurses. The primary data are obtained through questionnaire; further, data analysis method utilizes Partial Least Square (PLS). The results demonstrate that strategic human resource management practice significantly influences knowledge management; knowledge management significantly influences service quality and organizational performance. Service quality influences organizational performance significantly. Strategic human resource management practice, as mediated by knowledge management, brings significant effect on the service quality and organizational performance. Limitation of this research shows that the strategic human resource management practice variable includes only three indicators such as training, job opportunities, and job security so that it affects on the estimation result which is not yet optimum. Therefore, for further research, it is suggested to involve other strategic human resource management practice indicators to make the result more optimum. This research utilizes service quality and organizational performance variables that are measured from internal organization perspective; this measurement source possibly results in bias information. To obtain more objective information, further research is suggested to involve external parties or the customers/patient
\end{abstract}

Keywords: strategic human resource management practice, service quality, organizational performance

\section{Introduction}

Well-established hospital organization management is much needed to make the organization preeminent and enhance its competitiveness position in long term. Thus, to attain good hospital organization performance, hospital service quality should be customer-oriented and directed to obtain market strength. It demands to shift the orientation of a hospital from social organization to socio-economic organization so that customer retention will be the main objective to achieve.

Assauri [1] stated that customers tend to look for a product or service from an organization which is able to provide best service for them. Raju and Lonial [2] confirmed that service quality and marketing influence financial performance of a hospital organization. Harrington and Akehurst [3]; Gilbert and Guerrier [4] mentioned that there is positive correlation between service quality and organizational performance in hotel and hospitality service industry. Hoque $[\mathbf{5 , 6 ]}$ said if hotel and hospitality service want to obtain performance improvement, it should emphasize more on service quality. Ahmad, et.al. [7] proved that there is positive relationship between service quality and conventional bank's performance though it is not quite strong. Service quality is assumed as imperative variable to achieve organization's competitive advantage for maintaining long term relationship with the customers (Zeithaml et.al.,[8]).

Lado, Agustin. A, and Mary C. Wilson [9] revealed that strategic human resource management is very potential in creating competitive advantage of an organization for achieving high performance. Either high quality product or excellent service quality that has strategic human resource dimension is the approach to create organizational competitive advantage for achieving high performance (Mathis and Jackson [10]). Specifically, some parts that become the focus of the consideration are whether strategic human resource management practice policy that has been established by organization is already good, related to employee's comfort, selection and recruitment policy, extensive training, learning and development, compensation policy on employee group, and a set of human resource management policy (Pfeffer [11]). The issues on the strategic human resource management practice become more and more important to enhance organizational performance related to the core competence, intellectual capital, organization ability, high performance system, process management, value-based team, and high performance team (Ulrich, Dave [12]). 
Greer [13] examined the relationship between human resource strategies and organizational performance. Innovative strategic human resource management practice is able to contribute on the organizational economics performance enhancement. Cho, Seonghee et.al. [14] empirically proved that an organization which implements strategic human resource management practice such as workforce management participation program, initiative plan, and selection test, experiences positive influence on single organizational performance measurement as it results on the low turnover rate among nonmanagerial employees; yet, there is no significant influence of the human resource management practice's 12 items on other indicators of the organizational performance.

Empirical study that used universal relevance indicators of human resource management practice such as external fit and internal fit did not provide significant role on the Barbados hotel's performance (Alleyne, Doherty, Greenidge, 2005 [15] and Guest [16] stated that the process and the form of relationship between strategic human resource management practice and organizational performance had not yet produced more valid and more accurate estimation model.

Chen \& Huang [17] said that knowledge management capacity positively and significantly influences organizational innovation performance. It means that organizational innovation performance will be better if the knowledge management capacity which includes knowledge acquisition, knowledge sharing, and knowledge application dimensions, is developed well. Hsu [18] also stated that knowledge management/sharing positively influences organizational performance improvement. Knowledge management involves strategy and process of identifying, capturing, managing, sharing, and implementing individual or organizational knowledge to explore competitive advantage that is useful to achieve high organizational performance as well as to create sustainable organizational resource development (Alavi \& Leidner [19]; Davenport \& Prusak [20]); Holsapple and Joshi, [21]; Liebowitz [22]; Nonaka \& Takeuchi [23]). Knowledge management is an organizational concept comprising integrated, coordinated, and intended, and deliberated effort to manage organizational knowledge through the processes of creation, management, distribution, and implementation in order to enhance organizational performance as well as to create value (Bose [24]).

Chand, Mohinder [25] in his research mentioned that strategic human resource management practice is able to bring impact on service quality and organizational performance. Strategic human resource management practice is even able to create customer-oriented employee behavior; besides, it also brings significant impact on service quality and customer satisfaction. However, there are only a few empirical studies in the context of strategic human resource management practice role on service quality as seen from the customer perspective (Tsaur \& Lin [26]).

Chyn and Kaliannan [27] showed different result related the human resource management practice on the logistic service industry. Even it had conducted good 25 strategic human resource management practices, it was not able to change service quality of the logistic driver staffs to be better. It means that the implementation of strategic human resource management practices does not result on the service quality change.

The empirical research has proven that knowledge management is able to support human resource in order to enhance service quality (Bose [24]; Orzano et.al,[28]; Chen and Huang, [17]). Knowledge management can make an organization preeminent in the competition, including in knowledge average improvement, service quality improvement, cost and time reduction, relationship strengthening among peer workers, and faster knowledge creation (Su \& Lin [29]).

In dynamic and competitive business environment, strategic human resource management practice and knowledge management have imperative role that is related each other. Knowledge management has been recognized as the essential resource to achieve organizational competitive advantage (Karl [30]). Knowledge era requires new paradigm in managing strategic human resource management practice. It is needed to provide chance that highly contributes on the strategic human resource management practice in order to achieve more effective organization. Strategic human resource management practice should be able to deliver new paradigm in managing an organization through knowledge that the organization has (Karl [30]). Strategic human resource management practice is expected to able to improve some activities, not only responsible for the recruitment, selection, compensation, and labor union, but also responsible for new activities implementation such as skill, leadership, creativity, and innovation development, making change and transformation management, creating learning organization, etch (Raich [31]).

From the organizational learning perspective, Currie and Kerrin [32] used case study approach to examine the role of strategic human resource management practice, consisting of performance management, recruitment and selection, employee interaction, and career development, on knowledge sharing improvement in an organization. They recommended that strategic human resource management practice is able to enhance knowledge management/sharing functionally based on the structure and the culture of the organization. 


\section{Literature Review and Conceptual Model}

\subsection{Strategic Human Resource Management Practice and Organizational Performance}

Human resource management scholars show their high interest on the strategic human resource management practice in organization. Strategic human resource management practice is also called as "high performance work system" (Appelbaum et.al. [33]), high commitment human resource management (Guest [34]), or high involvement human resource management (Wood [35]). Strategic human resource management practice or human resource management bundles are a set of strategic human resource management practice activities that have a potential to enhance organizational performance. It has been proven that there is a significant relationship among system and strategic human resource management practice on organizational performance (Lado and Agustin [9]); moreover, the strategic human resource management practice is considered to be able to create competitive advantage for an organization since the strategic human resource management practice can be utilized a source of the efficiency improvement for an organization as well as its source of value creation.

During last decade, many empirical studies have confirmed positive relationship of high performance human resource management or strategic human resource management practice and policy toward organizational performance (Arthur [36]; Huselid dan Delaney [37]; Huselid [38]; MacDuffie [39]).

Strategic human resource management scholars in recent decade have focused their research on the ability or internal consistency and system synergy of strategic human resource management bundles that is also called as strategic human resource management practice in order to generate human resources with high competence, particularly if it is combined with organizational strategies (Arthur [36]; Dyer \& Reeves [40]; Ichinowski et al.[41]; MacDuffie[39]). Yet, the theory development still has a few empirical supports, mainly for service sector.

\subsection{Knowledge Management}

In broad sense, knowledge management is a business concept consisting of integrated, coordinated, and deliberated efforts to manage organizational knowledge through the processes of creation, management, distribution, and implementation in order to enhance organizational performance as well as to create value.

Based on the definition of www.worldIQ.com [42], knowledge management is a belief that is recognized which includes its explicit and implicit meanings (Rachmany \& Akib [43]). Meanwhile, management is planning and controlling processes on the performance of various activities. Sykrme [44] defines knowledge management as a process that is able to assist organization in finding, selecting, distributing, and transferring crucial information that is needed for some activities such as problem solving, dynamic learning process, as well as planning strategy and decision making. Nonaka [45] interprets knowledge management as an effort to collect, organize, and create new knowledge, and then distribute it to the organization, as well as utilize the knowledge on the new technology and product. Organizational knowledge is an integration of individual and organizational knowledge that is managed to be competitive advantage. Knowledge management is a continuous process that should be conducted by organization. The process will become an organizational culture which shapes knowledge-based organization.

\subsection{Service Quality}

Cronin and Taylor [46], Oliver [47], and Zeithaml, Berry and Parasuraman [48] mentioned, service quality definition usually delineates whether the perceived service meets, exceeds, or fails to satisfy customer's needs. Czepiel [49] defines service quality, as customer's perception on how good a service can meet or go beyond the customer's expectation on the service, generally is noted as the critical requirement and competitiveness' driver to build and retain satisfying relationship with customers. Awareness on service quality makes an organization different from other organizations and achieves sustainable competitive advantages (Boshoff and Gray, [50]).

Service quality can be measured from customer perception, customer expectation, customer satisfaction, and customer attitude (Sachdev and Verma [51]). Service quality evaluation leads to customer satisfaction (Ekinci [52]).

\subsection{Organizational Performance}

Organizational performance is the outcome of activities that is obtained by an organization during particular time. Organization executives have understood that traditional performance measurement based on financial accounting concept such as return on investment (ROI) and earnings per share have some drawbacks. Balanced scorecard concept becomes widely spoken. Balanced scorecard concept sees that in measuring organizational performance, it is not only the financial perspective to be considered but also performance measurement based on human resource or organizational learning, business process, and customers as well. To portray organizational performance, financial statement that has been widely used until recent days does not 
involve intangible matters such as commitment, loyalty, and satisfaction. From these drawbacks, then there occurs a need on the performance measurement concept which is more comprehensive as adopted in the balanced scorecard.

Norton and Kaplan [53] introduced balanced scorecard which emphasizes on all of the financial and nonfinancial measures that becomes information system for workers at all levels in the organization. The objective and measurement in balanced scorecard are more than just a group of financial and non-financial performance measurements as all of the objectives and measurements are derived and driven by mission and strategy of the organization.

Balanced implies steadiness between strategy and performance from several perspectives; scorecard describes simple measurement needs as perceived from strategy and decision making. Four organizational performance measurements in balanced perspective (balanced scorecard) are finance, customers, internal business process and learning process, and growth. Balance scorecard is utilized to interpret organization's vision and mission through four perspectives.

Based on literature review, the conceptual model of this research is presented in Fig. 1.

Figure 1. Research Conceptual Model

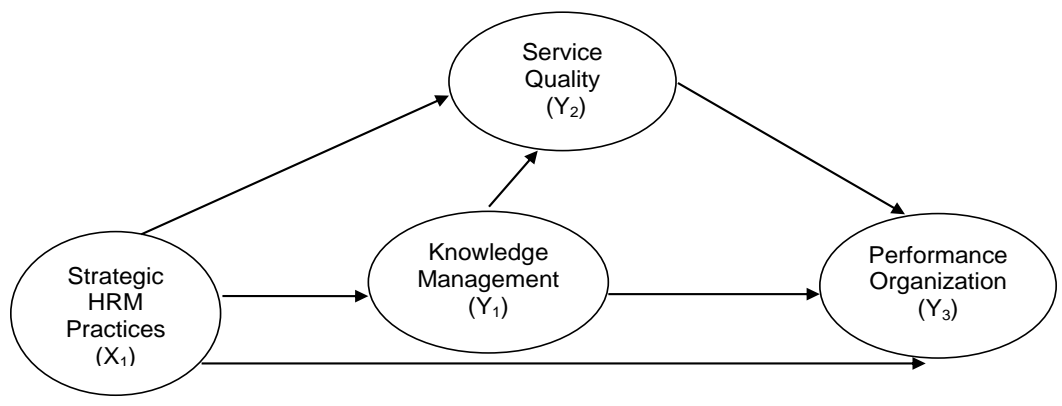

\subsection{Research Hypothesis}

\subsubsection{Strategic human resource management practice and Service Quality}

Human resource management emphasizes that to enhance organization's service quality, it should be focused on the training and development, selection, and compensation (Lovelock [54], Schneider [55]; Chand, Mohinder and Katou [56]). Strategic human resource management practice and human resource management perspective significantly influence customer's perception on service quality (Schneider [55]). It is also confirmed that in service industry, there is positive role of human resource perspective and strategic human resource management practice on service quality effectiveness evaluation (Gilbert [57], Tornow and Wiley [58], Hoque [5],[6], and Hung [59]). Therefore, based on the description, it leads to the following hypothesis:

Hypothesis 1: strategic human resource management practice directly and significantly influences service quality.

\subsubsection{Strategic human resource management practice and Knowledge Management}

Human with knowledge, skill, and expertise capitals is a precious resource of an organization (Lado and Wilson [9], Delery and Doty [60], Wright et al, [61], and Collins \& Clark [62]). Organization that effectively manages and utilizes potential knowledge and skill in an individual's thought will be able to create value add and achieve competitive advantage (Ruggles [63] and Scarbrough [64]). However, human resource often does want or is not able to share knowledge and skill to others in organization due to individual interest and lack of trust (Currie \& Kerrin [32], Hayes \& Walsham [65], Mueller \& Dyerson [66], and Davenport \& Prusak [20]). Hence, it is important for organization to utilize, involve, and encourage its human resource participation on knowledge management. Strategic human resource management practice is the main approach to achieve and improve human resource's knowledge and skill that are needed by an organization (Martinsons [67], Youndt et al. [68], and Collins \& Clark [62]). As there are a lot of human resources who share special knowledge and organizational expertise, possibly the most proper step to take for organization is by utilizing strategic human resource management practice in order to manage its knowledge and expertise (Scarbrough and Carter [69], Lave J, and Wenger E [70]). Therefore, strategic human resource management practice is the key elements to enable an organization in enhancing its competence on distributing and facilitating knowledge management. It means that strategic human resource management practice is able to motivate human resource's willingness to support favorable environment for developing knowledge management activity. Based on this description, it comes to the proposed hypothesis below:

Hypothesis 2: strategic human resource management practice directly and significantly influences knowledge management 


\subsubsection{Knowledge Management and Service Quality}

Organization's knowledge management can contribute to the continuous quality improvement. Service quality is assumed as the ability to meet the expressed requirement and implied requirement of the customers. Knowledge management about customers enables organization to understand them better, mainly related to the implied meaning for customers. By comprehending this situation, organization will be able to deliver product or service that is more suitable by asking for comment and perspective of the customers about quality. Getting in touch and listen to the customers are important for an organization when it wants to manage change and achieve competitiveness (Peters [71]). An organization also needs to understand not only the perspective of internal stakeholder's interest but also its external stakeholder's interest such as from its customers to provide clear direction and prevent error during development effort (Russel [72]). Hence, the service quality of a knowledgebased organization can be improved directly by implementing knowledge management in the organization for the purpose of making knowledge utilization that is needed to deliver service is better. This description leads to the following hypothesis:

Hypothesis 3: Knowledge management directly and significantly influences service quality

\subsubsection{The Role of Knowledge Management $\left(\mathbf{Y}_{1}\right)$ on Organizational Performance $\left(\mathbf{Y}_{3}\right)$}

Knowledge management is a more active approach in creating value and improving organization's effectiveness (Ruggles [63] and Scarbrough [64]). Organization that demonstrates better level of experience and better learning outcome of knowledge management is able to improve their ability to reduce redundancy, quickly responding to change, and developing creative and innovative idea (Scarbrough [64]). Effective knowledge management facilitates communication and knowledge exchange that are needed in the innovation process; further, it will improve innovation performance of an organization by developing new insight and ability (Madhavan \& Grover [73], Nonaka \& Takeuchi [23], Von Krogh [74]). Therefore, knowledge management plays important role in supporting organizational performance improvement. Since knowledge in organizational performance management process is complex, then it should be focused on a mechanism to utilize, obtain, share, and implement new knowledge for improving organizational performance. For this reason, it leads to the following hypothesis:

\section{Hypothesis 4: Knowledge management directly and significantly influences organizational performance}

\subsubsection{The Role of Strategic human resource management practice $\left(\mathrm{X}_{1}\right)$ on Organizational} Performance $\left(\mathbf{Y}_{3}\right)$

The important role of strategic human resource management practice to develop competitive advantage of an organizational in a knowledge-based economic rapidly changes; some of the researchers had focused their attention to examine the determinant of strategic human resource management practice (Tannenbaum and Dupuree-Bruno [75]) that influence organizational outcome such as productivity and efficiency (MacDuffie [39], Ichniowski et al.[41], Youndt et al. [68]) and financial performance (Delery \& Doty [60], Pfeffer [76], Mendelson \& Pillai [77], and Collins \& Clark [62]).

Hoque [5],[6] supported an analysis that hotels in England adopted strategic human resource management practice to improve their performance by making cost control and emphasizing on service quality. Besides, Hoque [5] also found that the relationship between strategic human resource management practice and organizational performance depended on the hotel's business strategy and hotels which utilized strategic human resource management practice focusing on service quality in best business strategy. Katau and Budhwar [78] in their research found that strategic human resource management practice policy on recruitment, training, promotion, incentive, allowance, health involvement and safety significantly affected organizational performance.

Strategic human resource management practice can influence and alter attitude, capacity, and behavior of human resource to achieve organization's objectives (Collins \& Clark [62] and Martinsons [67]); furthermore, strategic human resource management practice plays important role in maintaining the needed condition to catalyze and distribute individuals to the innovation activity direction (Scarbrough [64], Laursen \& Foss [79], and Michie \& Sheehan [80]). Organization can use some strategic human resource management practice such as staffing, training, participation, performance appraisal, compensation, etc. as they ways to motivate the commitment of its human resource and accept their involvement of thinking process as well as creative innovation (Damanpour [81] and Laursen \& Foss [79]). Thus, it comes to the following hypothesis:

Hypothesis 5: strategic human resource management practice significantly influences organizational performance 


\subsubsection{The Role of Service Quality on $\left(\mathbf{Y}_{2}\right)$ Organizational Performance $\left(\mathbf{Y}_{3}\right)$}

Morre [82] demonstrated that service quality was able to improve organization's competitive advantage for long term benefit. Service quality is perceived as the crucial indicator to obtain organization's competitive advantage for retaining long-term relationship with customers [83].

Ahmad et al.[7] in their research about "How Service Quality Affects Performance of Conventional Banks in Pakistan" showed that there was positive relationship between service quality and conventional bank's performance, though the relationship is not quite strong. They recommended that to achieve better performance of the conventional bank in the future, the bank executives should improve their service quality by integrating traditional facility and modern technology to meet the customer expectation. Based on this description, this research proposes the following hypothesis:

Hypothesis 6: Service quality significantly influences organizational performance

\subsubsection{The Role of Strategic Human Resource Management Practice $\left(X_{1}\right)$ Mediated by Service Quality $\left(\mathbf{Y}_{2}\right)$ on Organizational Performance $\left(\mathbf{Y}_{3}\right)$}

The effort to improve service quality should be focused on training, development, selection, and compensation (Lovelock [54], Schneider [55], Chand, Mohinder, and Katou [56]). Next, Ulrich, Halbrook, Meder, Stucchlik, and Thorpe [89] mention that selection, recruitment, appraisal, promotion, reward and administration practice can be utilized to improve shared mind-set among employees and customers that is directed to the organization in attracting customers as well as enhancing competitiveness. It means that when the employees are well-served by strategic human resource management practices, they can devote their energy and resource to effectively deliver the service in retaining customers.

Service quality is the core sustainability of a service organization. Quality revolution movement through integrated quality management approach becomes a requirement that cannot be ignored when a service organization wants to survive and develop. A service organization always cares for its customers by delivering excellent service. Customers will search for product and service that can deliver best service to them (Assauri [1]). Service quality is perceived as crucial indicator of organizational performance that can helps to obtain organization's competitive advantage in retaining long term relationship with customers (Zeithmal et al.[8)]

To conclude, in revealing cross-functional reviews that positive relationship of each variable has significant role on the overall growth and development of an organization. Therefore, it needs to confirm the relationship among variables such as strategic human resource management practice, service quality, and organizational performance. To provide further empirical evidence, then it leads to the following hypothesis:

Hypothesis 7: strategic human resource management practice mediated by service quality significantly affects organizational performance.

\subsubsection{The Role of strategic human resource management practice $\left(X_{1}\right)$ Mediated by Knowledge} Management $\left(\mathbf{Y}_{1}\right)$ on Service Quality $\left(\mathbf{Y}_{2}\right)$

Knowledge era requires new paradigm on strategic human resource management practice. It is really needed to give chance for strategic human resource management practice to contribute on achieving more effective organization. Strategic human resource management practice should be able to deliver new thought in managing the organization through the knowledge they have (Karl [30]). Strategic human resource management practice is expected to be able to improve its activities not only responsible for activities such as recruitment, selection, compensation, labor union, etc. but also for new activities such as new competence development, skill, leadership, creativity and innovation enhancement, conducting change management and transformation, becoming learning organization, etc. (Raich, [31])

From service perspective, organization knowledge management can contribute on the continuous quality improvement. Service quality is assumed as the ability to fulfill explicit and implicit requirements of the customers. Organization knowledge management related to customers enables a business organization to understand their customers better, mainly related to what is implied by the customers. The integration of strategic human resource management practice and knowledge management is expected to be able to improve service quality. Thus, this research proposes the following hypothesis:

Hypothesis 8: strategic human resource management practice, mediated by knowledge management, significantly influences service quality.

\subsubsection{The Role of strategic human resource management practice $\left(X_{1}\right)$ Mediated by Knowledge} Management $\left(\mathbf{Y}_{1}\right)$ on Organizational Performance $\left(\mathbf{Y}_{3}\right)$

This description focuses on the measurement of strategic human resource management practice effect on organizational performance mediated by knowledge management as the development of prior strategic human resource management practice concept and innovativeness. Youndt et al. [68], Collins \& Clark [62], Currie \& Kerrin [32], Tannenbaum \& Dupuree-Bruno [75], and MacDuffie [39] argued that the relationship was even 
tighter in the involvement of strategic human resource management practice, knowledge management, and innovation performance of the organization. Explicitly, it shows that strategic human resource management practice affects organizational performance mediated by knowledge management. It means that organization can utilize a set of strategic human resource management practice to develop or strengthen knowledge acquisition level, knowledge sharing, and knowledge application which in turn strategic human resource management practice will also be able to improve organizational performance. Hence, knowledge management plays mediation role in the relationship between strategic human resource management practice and organizational performance. Therefore, this research proposes the following hypothesis:

Hypothesis 9: strategic human resource management practice mediated by knowledge management significantly influences organizational performance.

\section{a. Population and Sample}

\section{Research Method}

Research population is all of the public and private hospitals in South Kalimantan (Indonesia). The numbers of hospitals are 28 units consisting of 15 public hospitals and 8 private hospitals. The sampling technique used in this research is saturated sampling as all of the population are involved as the sample due to the small number of the total population. To represent each hospital, this research defines 5 respondents from each hospital that counts as many as 115 respondents.

\subsection{Data Collection and Analysis Methods}

Research data consist of primary and secondary data. Primary data are obtained directly from the predetermined respondents from both public and private hospitals in South Kalimantan; meanwhile, the secondary are collected from several sources such as Medical and Health Department of South Kalimantan Province, Indonesia Statistic Bureau (BPS/ Badan Pusat Statistik) reference, and other relevant publication with this research. The data are attained by using questionnaire which is distributed to the respondents. Data measurement uses Likert's scale from 1 to 5 intervals. It starts from 1 (strongly disagree) to 5 (strongly agree). Data analysis technique employs Partial Least Square (PLS).

\subsection{Validity and Reliability}

The indicator of latent variable (construct) is valid if it has loading factor which is higher than 0.05 or the t-statistic is higher than t-table (>1.96); in addition, latent variable (construct) is reliable when the composite reliability score of one variable is higher than 0.70 . The validity and reliability tests of the latent variable (construct) are presented in Table 1.

Table 1. Measurement of observed Variables

\begin{tabular}{|c|c|c|c|c|c|}
\hline $\begin{array}{c}\text { Component and manifest } \\
\text { variable }\end{array}$ & Indicator & Loading Factor & t-value & $\begin{array}{l}\text { Composite } \\
\text { Reliability }\end{array}$ & AVE \\
\hline \multirow{3}{*}{ Strategic HRM Practices } & \multirow{3}{*}{$\begin{array}{l}\text { Training } \\
\text { Opportunities } \\
\text { Job insecurity }\end{array}$} & 0.872 & 20.828 & \multirow{3}{*}{0.906} & \multirow[t]{3}{*}{0.762} \\
\hline & & 0.855 & 22.973 & & \\
\hline & & 0.891 & 33.776 & & \\
\hline \multirow{4}{*}{ Knowledge Management } & \multirow{4}{*}{$\begin{array}{l}\text { Explicit Knowledge } \\
\text { Tacit Knowledge } \\
\text { External Knowledge } \\
\text { Internal Knowledge }\end{array}$} & 0.894 & 48.308 & \multirow{4}{*}{0.878} & \multirow{4}{*}{0.649} \\
\hline & & 0.609 & 5.867 & & \\
\hline & & 0.919 & 67.884 & & \\
\hline & & 0.762 & 9.148 & & \\
\hline \multirow{5}{*}{ Service Quality } & \multirow{5}{*}{$\begin{array}{l}\text { Tangible } \\
\text { Reliability } \\
\text { Responsiveness } \\
\text { Assurance } \\
\text { Empathy }\end{array}$} & 0.807 & 20.920 & \multirow{5}{*}{0.927} & \multirow{5}{*}{0.718} \\
\hline & & 0.908 & 44.256 & & \\
\hline & & 0.889 & 38.795 & & \\
\hline & & 0.896 & 36.040 & & \\
\hline & & 0.721 & 12.204 & & \\
\hline
\end{tabular}

Notes: $t$-value $=$ significant at $\alpha=0.05$, and loading factor $>0.50$ and Composite Reliability $>0.70$

Goodness of Fit test of the structural modeling uses predictive-relevance value $\left(Q^{2}\right) . Q^{2}$ can be calculated based on the each endogenous variable's $\mathrm{R}$-Square $\left(\mathrm{R}^{2}\right)$. The calculation result of the $\mathrm{Q}^{2}=1-(1-0.438)(1$ 0.363 ) (1-0.559) is 0.84248 . It means that based on the calculation, it results on the 0.84248 predictive-relevance value. It implies that the research model is good as it is able to explain the organizational performance phenomenon as much as $84.25 \%$; while the rest $(15.75 \%)$ is explained by other variables that are not included in this model and error.

\section{Results and Analysis}

Respondents' perception on the indicators of each variable is judged form the loading factor score and the mean score. The loading factor score shows indicator's contribution conceptually in reflecting its variable; 
whereas the mean score describes the perception of medical staff or nursing staff on the indicators of each variable, which reflects the real description of the research variable.

Table 2

Loading Factor and Mean Score of the Indicators of each Variable

\begin{tabular}{|c|c|c|c|}
\hline Variable & Indicator & Loading Factor & Mean \\
\hline \multirow{3}{*}{ Strategic HRM Practices $\left(\mathrm{X}_{1}\right)$} & \multirow{3}{*}{$\begin{array}{l}\mathrm{X}_{1.1} \\
\mathrm{X}_{1.2} \\
\mathrm{X}_{1.3}\end{array}$} & 0.872 & 4.17 \\
\hline & & 0.855 & 4.31 \\
\hline & & 0.891 & 4.10 \\
\hline \multirow{4}{*}{ Knowledge Management $\left(\mathrm{Y}_{1}\right)$} & \multirow{4}{*}{$\begin{array}{l}\mathrm{Y}_{1.1} \\
\mathrm{Y}_{1.2} \\
\mathrm{Y}_{1.3} \\
\mathrm{Y}_{1.4}\end{array}$} & 0.894 & 3.67 \\
\hline & & 0.609 & 3.83 \\
\hline & & 0.919 & 3.55 \\
\hline & & 0.762 & 3.68 \\
\hline \multirow{5}{*}{ Service Quality $\left(\mathrm{Y}_{2}\right)$} & \multirow{5}{*}{$\begin{array}{l}\mathrm{Y}_{2.1} \\
\mathrm{Y}_{2.2} \\
\mathrm{Y}_{2.3} \\
\mathrm{Y}_{2.4} \\
\mathrm{Y}_{2.5}\end{array}$} & 0.807 & 3.70 \\
\hline & & 0.908 & 3.99 \\
\hline & & 0.889 & 3.98 \\
\hline & & 0.896 & 4.05 \\
\hline & & 0.721 & 3.86 \\
\hline \multirow{4}{*}{ Organizational Performance $\left(\mathrm{Y}_{3}\right)$} & \multirow{4}{*}{$\begin{array}{l}\mathrm{Y}_{3.1} \\
\mathrm{Y}_{3.2} \\
\mathrm{Y}_{3.3} \\
\mathrm{Y}_{3.4}\end{array}$} & 0.568 & 3.99 \\
\hline & & 0.673 & 3.57 \\
\hline & & 0.907 & 3.80 \\
\hline & & 0.833 & 3.97 \\
\hline
\end{tabular}

Table 2 displays that job insecurity indicator scores 0.891 for its loading factor which becomes the dominant indicator in shaping strategic human resource management compared to job training (0.872) and job opportunity (0.855). If it is correlated to the respondent's perception, they commonly choose job insecurity which gets 4.10 mean score. On the contrary, it does not become the main consideration for public hospitals. The evidence indicates that, in fact, respondents perceive that job opportunity (4.31) is more important than job training and job insecurity for hospital organization. External knowledge indicator has 0.919 loading factor score as the dominant indicator in shaping knowledge management variable compared to the other indicators such as explicit knowledge (0.894), internal knowledge (0.762), and tacit knowledge (0.609). If it is associated with the respondents' perception, they commonly choose external knowledge which gets 3.55 mean score. On the contrary, external knowledge does not become the main consideration for the hospital organization. The proof shows that, in fact, respondents perceive that tacit knowledge (3.83) is more important for hospital organization than explicit knowledge (3.67), external knowledge (3.55), and internal knowledge (3.68) indicators.

Reliability indicator obtains 0.908 loading factor score as the dominant indicator which constructs service quality variable compared to tangible (0.807), responsiveness (0.889), assurance (0.896) and empathy (0.721). If it is correlated to the respondent's perception, they commonly choose reliability indicator with 3.99 mean score. On the contrary, it does not become the main consideration for hospital organization. The evidence indicates that, in fact, respondents perceive that assurance indicator (4.05) is more important for hospital organization than tangible (3.70), responsiveness (3.98), and empathy (3.86) indicators.

Internal business process indicator scores 0.907 for its loading factor which becomes the dominant indicator in shaping organizational performance variable compared to financial perspective (0.568), customer perspective (0.673), as well as learning and growth perspective (0.833) indicators. If it is associated to the respondent's perception, they commonly choose internal business process which has 3.80 mean score; whereas, it does not become the main consideration for a hospital. The evidence demonstrates that in fact respondents perceive that financial perspective (4.99) is more important for hospital organization than customer perspective indicator (3.57), internal business process perspective (3.80), as well as learning and growth (3.97) indicators.

Based on the Table 3 of hypothesis testing and path coefficient result, it shows that the four paths of the relationship are significant. It is confirmed by the t-statistic score which is higher than its t-table (1.96). The path coefficient of strategic human resource management practice variable toward knowledge management is 0.661 with 11.474 t-statistic score; the path coefficient of knowledge management toward service quality is 0.573 with 6.581 t-statistic score; the path coefficient of knowledge management toward organizational performance is 0.378 with 3.999 t-statistic score; and the path coefficient of service quality toward organizational performance is 0.512 with $4.500 \mathrm{t}$-statistic score. Two paths of relationship show not significant effect. It is verified with the t-statistic score which is lower than its t-table $(<1.96)$ as the path coefficient of strategic human resource management practice variable toward service quality is 0.044 with 0.39 t-statistic score; the path coefficient of strategic human resource management practice toward organizational performance is 0.093 with 0.939 t-statistic score. However, from the indirect effect test or mediation effect, the relationship of the two paths becomes significant. Table 3 .

The hypothesis test result on direct and indirect effects among research variables are presented in the 
Table 3. Hypothesis Testing and Path Coefficient for PLS

\begin{tabular}{|c|c|c|c|c|c|c|c|c|}
\hline No & \multicolumn{5}{|c|}{ Direct Effect } & $\begin{array}{c}\text { Path } \\
\text { Coefficient }\end{array}$ & t-value & Empirical Evidence \\
\hline 1 & \multicolumn{5}{|c|}{ Strategic HRM Practices $\rightarrow$ Service Quality } & 0.044 & 0.391 & Not Significant \\
\hline 2 & \multicolumn{5}{|c|}{ Strategic HRM Practices $\rightarrow$ Organizational Performance } & 0.093 & 0.939 & Not Significant \\
\hline 3 & \multicolumn{5}{|c|}{ Strategic HRM Practices $\rightarrow$ Knowledge Management } & 0.661 & 11.474 & Significant \\
\hline 4 & \multicolumn{5}{|c|}{ Knowledge Management $\rightarrow$ Service Quality } & 0.573 & 6.581 & Significant \\
\hline 5 & \multicolumn{5}{|c|}{ Knowledge Management $\rightarrow$ Organizational Performance } & 0.378 & 3.990 & Significant \\
\hline 6 & \multicolumn{5}{|c|}{ Service Quality $\rightarrow$ Organizational Performance } & 0.512 & 4.500 & Significant \\
\hline \multicolumn{9}{|c|}{ Test For The Impact Of Mediating Variable } \\
\hline & \multicolumn{2}{|l|}{ Exogenous } & \multicolumn{2}{|c|}{ Mediation } & Endogenous & Path Coefficient & $\begin{array}{c}\text { Mediation } \\
\text { Attribution }\end{array}$ & Empirical Evidence \\
\hline 1. & $\begin{array}{l}\text { Strategic HRM } \\
\text { Practices }\end{array}$ & $\rightarrow$ & Service Quality & $\rightarrow$ & $\begin{array}{l}\text { Organizational } \\
\text { Performance }\end{array}$ & 0.407 & $\begin{array}{l}\text { Complete } \\
\text { Mediation }\end{array}$ & Significant \\
\hline 2. & $\begin{array}{l}\text { Strategic HRM } \\
\text { Practices }\end{array}$ & $\rightarrow$ & $\begin{array}{c}\text { Knowledge } \\
\text { Management }\end{array}$ & $\rightarrow$ & Service Quality & 0.814 & $\begin{array}{l}\text { Complete } \\
\text { Mediation }\end{array}$ & Significant \\
\hline $3 .$. & $\begin{array}{l}\text { Strategic HRM } \\
\text { Practices }\end{array}$ & $\rightarrow$ & $\begin{array}{c}\text { Knowledge } \\
\text { Management }\end{array}$ & $\rightarrow$ & $\begin{array}{l}\text { Organizational } \\
\text { Performance }\end{array}$ & 0.634 & $\begin{array}{l}\text { Complete } \\
\text { Mediation }\end{array}$ & Significant \\
\hline
\end{tabular}

Note: $t$-value $=$ significant at $\alpha=0.05(t$-statistic value $>1.96)$

The hypothesis testing result of the direct effect between strategic human resource management practice and service quality shows the path coefficient is 0.044 and the t-statistic is 0.391 . Those scores are far below the t-table (1.96). This result proves that strategic human resource management practice does not significantly influence service quality. Thus, the hypothesis (H1) which states that strategic human resource management practice significantly influences service quality is not accepted. However, this research does not prove the direct effect but it shows positive path coefficient score which implies uni-directional (linear) relationship. Therefore, it can be interpreted that well-implemented strategic human resource management practice is potential to improve service quality in hospital.

The hypothesis testing result on the direct effect of strategic human resource management practice toward knowledge management obtains 0.661 path coefficient and $11.474 \mathrm{t}$-statistic; those score is higher than $\mathrm{t}$ table (1.96). This result confirms that strategic human resource management practice significantly and positively influences knowledge management. Therefore, the hypothesis $(\mathrm{H} 2)$ which states that strategic human resource management practice significantly influences knowledge management is accepted. When the effect is positive and significant, it indicates that better strategic human resource management practice implementation results in better knowledge management of the hospital organization.

The hypothesis test result on the direct influence of knowledge management variable on service quality scores 0.573 for its path coefficient and 6.581 of t-statistic. This value is higher than its t-table (1.96). It confirms that the effect of knowledge management is significant and positive toward service quality. Thus, the hypothesis (H3) which states that knowledge management significantly influences service quality is accepted in this research. As the role is positive and significant, it can be interpreted that better implementation of knowledge management results in better service quality of the hospital organization.

The hypothesis test of knowledge management's direct effect on organizational performance obtains 0.378 path coefficient with 3.999 t-statistics. The $t$ value is higher than its t-table (1.96) meaning that knowledge management contributes significant and positive effect on organizational performance. Thus, the hypothesis (H4) which states that knowledge management significantly and positively influences organizational performance is accepted. It can be interpreted that better knowledge management implementation results in better organizational performance of a hospital.

The hypothesis test result on the direct effect of strategic human resource management practice toward organizational performance obtains 0.093 path coefficient with $0.939 \mathrm{t}$-statistics. This score is lesser than its $\mathrm{t}$ table (1.96) meaning that strategic human resource management practice does not have any significant effect on organizational performance. Therefore, the hypothesis (H5) which states that strategic human resource management practice significantly influences organizational performance is rejected. It implies that better strategic human resource management practice does not contribute to better organizational performance of a hospital.

The hypothesis test result on the direct effect of service quality variable toward organizational performance obtains 0.512 path coefficient with 4.500 t-statistics which is higher than its t-table (1.96). It confirms that service quality significantly and positively affects organizational performance. Thus, the hypothesis (H6) which states that service quality directly affects organizational performance is accepted. It indicates that better service quality results in better organizational performance of a hospital.

The hypothesis test result on the indirect effect of strategic human resource management practice toward organizational performance through service quality obtains 0.407 indirect effect coefficient with $4.532 \mathrm{t}$ statistic which is higher than its t-statistic (1.96). It confirms that strategic human resource management practice 
mediated by service quality significantly affects organizational performance. Therefore, the hypothesis $(\mathrm{H} 7)$ which states strategic human resource management practice mediated by service quality significantly affects organizational performance is accepted. It indicates that better strategic human resource management practice implementation through service quality support will result in better organizational performance of a hospital.

The hypothesis test on the indirect effect of strategic human resource management practice variable on service quality through knowledge management shows 0.814 indirect relationship path coefficient with $4.422 \mathrm{t}$ statistic; that score is higher than its t-table (1.96). This result validates that strategic human resource management practice mediated by knowledge management has positive and significant effect on service quality. Therefore, the hypothesis (H8) which states that strategic human resource management practice mediated by knowledge management significantly influences service quality is accepted. It implies that better strategic human resource management practice implementation supported by knowledge management will result in better service quality of the hospital organization.

The hypothesis test on the indirect effect of strategic human resource management practice variable on organizational performance through knowledge management obtains 0.634 coefficient of indirect effect with $4.532 \mathrm{t}$-statistic which is higher than its t-table (1.96). This result proves that strategic human resource management practice mediated by knowledge management significantly and positively affects organizational performance. Therefore the hypothesis (H9) which states that strategic human resource management practice significantly and positively influences organizational performance as mediated by knowledge management is accepted. It implies that better implementation of strategic human resource management practice through knowledge management support will result in better organizational performance of a hospital.

Hypothesis test result is presented in Figure 2.

Figure 2. Diagram for hypothesis testing and path coefficient for PLS

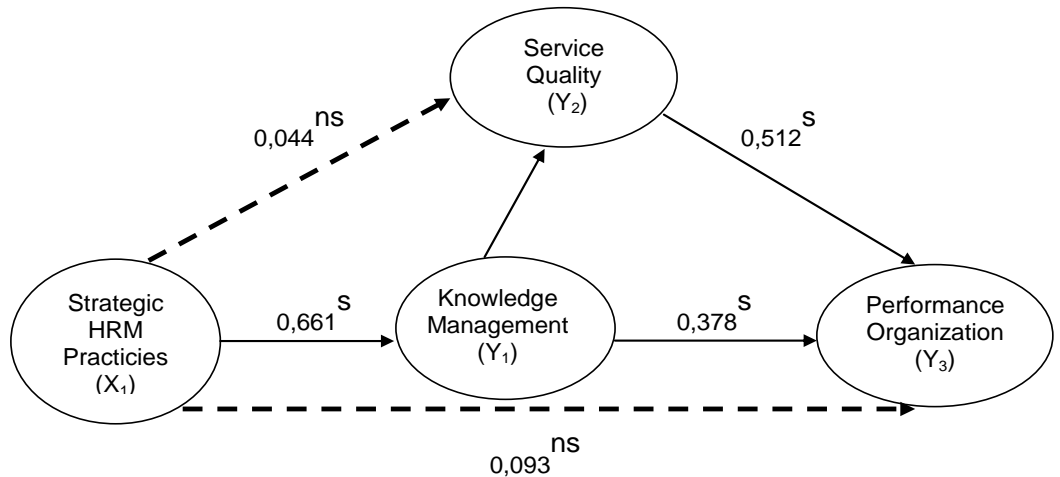

Note: $(\mathbf{s})=$ significant at $\alpha=0.05,(n s)=$ not-significant

\section{Discussion}

As reflected on the Table 3, the hypothesis test result (H1) between strategic human resource management practice and service quality does not provide any significant effect. It means that better implementation of strategic human resource management practice does not give higher contribution on the service quality refinement of the hospital. Statistically, the cause of the strategic human resource management practice's role which is not significant toward service quality is the implementation of each strategic human resource management practice's indicator is not yet optimum, mainly for job insecurity indicator. Table 2 describes that job insecurity is the dominant indicator (0.891) that shapes strategic human resource management practice; however, respondent's perception on the job insecurity indicator shows 4.10 mean score. In fact, job insecurity does not become the main consideration of the hospital organization to encourage better strategic human resource management practice implementation. This result is relevant with the result which states that strategic human resource management practice does not influence hospital's organizational performance (Chyn and Kaliannan [27]). This research is contradictory to the research of Lovelock [54], Schneider [55], Chand, Mohinder and Katou [56], Gilbert [57], Tornow and Wiley [58], Hoque [5][6], Hung [59], as these research stated that strategic human resource management practice affects hospital's organizational performance.

The hypothesis test result $(\mathrm{H} 2)$ on the relationship between strategic human resource management practice and knowledge management shows significant effect. This result can be interpreted that better strategic human resource management practice results on better knowledge management to improve service quality and organizational performance of the hospital. This result supports Currie and Kerrin's [32], finding as strategic human resource management practice is able to improve knowledge management/sharing functionally based on the structure and the culture of an organization. Other research result also confirms that effective organization 
which is able to manage and utilize potential knowledge and expertise in individual's mind will be able to create value-add and achieve competitive advantage (Ruggles [63] and Scarbrough [64]).

The hypothesis test result (H3) on the relationship between knowledge management and service quality is significant. It can be interpreted that better knowledge management implementation results on better service quality of a hospital. This research supports Su and Lin's [29] finding as it states that knowledge management can make an organization lead the competition including on the knowledge mean improvement, service quality enhancement, cost and time reduction, strengthening the relationship between peer workers, and create knowledge faster. Likewise, Huang, Li-Su et.al. [84] also explains that knowledge management is able to improve service quality.

The hypothesis test result $(\mathrm{H} 4)$ on the relationship between knowledge management and organizational performance is significant. This result indicates that better knowledge management implementation results on better organizational performance of a hospital. This research supports Liu et.al. [85] finding which confirms that knowledge management has significant effect on performance, particularly the performance on new product development. This research also confirms Zheng's et.al. [86], which proves that knowledge management causes positive and significant effect on organization's effectiveness as measured from overall performance, market share, growth rate, profitability, and organizational innovativeness. Furthermore, this research is relevant with Liao \& Wu's [87] which demonstrates significant and positive relationship between knowledge management and organizational innovation.

The hypothesis test result (H5) on the relationship between strategic human resource management practice and organizational performance shows not significant effect. It can be interpreted that better strategic human resource management practice does not contribute to better organizational performance refinement of a hospital. This research is relevant with Alleyne's et.al. [15] finding which mentions that universal relevance of human resource management, internal fit, and external fit do not affect hotel's performance significantly. Moreover, Cho, Seonghee et.al. [14] state that an organization which implements strategic human resource management practice such as participation program, labor management, plan initiative, and selection test only has positive effect on one performance measurement's item which is the low turnover level for non managerial workers. There is no significant proof of the strategic human resource management practice's 12 items on other organizational performance's items. This result is on the contrary with the research of Arthur [88], Huselid and Delaney [37], Huselid [38], MacDuffie [39], and Greer [13] which conclude that there positive relationship among high performance or practice and strategic human resource management practice policy toward organizational performance.

The hypothesis test result (H6) on the relationship between service quality and organizational performance demonstrates significant effect. It implies that better service quality results in better organizational performance of a hospital. This research supports Raju and Lonial's [2], Harrington and Akehurst [3], Gilbert and Guerrier [4], Hoque [5],[6], and Ahmad et.al. [7] research which confirm that service quality affects organizational performance.

The hypothesis test result (H7) on the relationship between strategic human resource management and organizational performance through service quality shows significant result. It means that better implementation of strategic human resource management practice supported by good service quality will result in better organizational performance of a hospital. This research describes that service quality is a complete mediation variable of the strategic human resource management practice's role toward organizational performance. This finding proves that strategic human resource management practice does not have any direct effect on organizational performance of a hospital, unless it is mediated by service quality. This research result supports Chand, Mohinder's finding [25] which states that strategic human resource management practice both directly and indirectly affects positively on the improvement of service quality and customer satisfaction as well as hotel performance.

The hypothesis test result (H8) on the relationship between strategic human resource management practice and service quality mediated by knowledge management is significant. It implies that better strategic human resource management practice implementation supported by good knowledge management results in better service quality of the hospital organization. This research provides a description that knowledge management is the complete mediation of the strategic human resource management practice's role on service quality. This finding proves that strategic human resource management practice is not the direct determinant of service quality; yet, its position is the crucial determinant of knowledge management to deliver refined or enhanced service quality of the hospital. This result indicates that strategic human resource management practice that is created through the process of knowledge management will be able to improve hospital's service quality. Better implementation of strategic human resource management practice results in better service quality of the organization through good knowledge management process.

The hypothesis test result (H9) on the role of strategic human resource management practice on organizational mediated performance by knowledge management is significant. It means that better strategic 
human resource management practice implementation results in better organizational performance of a hospital through the support of better knowledge management. This result justifies the finding of Chen \& Huang[17], Hsu, I-Chieh [18] which mention if the strategic human resource management practice is well-developed through the support of good knowledge management, it results in better achievement of organizational innovation.

\section{Research Limitation}

As the limitation of this research, strategic human resource management practice variable uses only three indicators such as job training, job opportunity, and job insecurity so that it makes the estimation result is not quite optimum. Thus, further research is suggested to involve others strategic human resource management practice's indicators to maximize the estimation result. This research does not use human resource management behavior variable, employee's outcome, employee's competence, as well as employee's commitment as the mediation variables to measure service quality and organizational performance even theoretically and conceptually those variables can be impactful. Hence, further research is suggested to include all of the variables as the mediation variables to estimate the role of strategic human resource management, service quality, and organizational performance. This research measures service quality and organizational performance of a hospital that are determined from internal organization's perspective; this measurement model may result in bias information. To achieve more objective information from research object, further research had better to involve external organization of the hospital such as customers/patients.

\section{Conclusion}

Strategic human resource management practice cannot directly enhance service quality and organizational performance of a hospital; yet the implementation of strategic human resource management practice is able to improve organizational performance well through good implementation of service quality. Thus, service quality is the complete mediation variable. Strategic human resource management practice that is reflected on the job training, job opportunities, and insecurity is able to improve the refinement of knowledge management in hospital organization. Service quality and organizational performance of a hospital can be elevated by implementing good knowledge management as reflected on the explicit knowledge, tacit knowledge, external knowledge, and internal knowledge as the source of reference to create new knowledge of an organization. The implementation of service quality as reflected on the tangibility, reliability, responsiveness, assurance, and empathy for customers/patients' needs is able to improve the performance of hospital organization.

\section{References}

[1] Assauri, San, 2003. "Customer Service yang Baik Landasan Pencapaian Customer Satisfaction" dalam Usahawan, No. 01, Tahun XXXII, Jakarta.

[2] Raju, P.S., Lonial, S.C. 2002. The Impact of Service Quality and Marketing on Financial Performance in the Hospital Industry: an Empirical Examination. Journal of Retailing and Consumer Service 9 (2002) 335-348.

[3] Harrington, D., and Akehurst, G. 1996, 'Service Quality and Business Performance in the UK Hotel Industry,' International Journal of Hospitality Management, 15, 283-298.

[4] Gilbert, D., and Guerrier, Y. (1997), 'UK Hospitality Managers Past and Present,' Service Industries Journal, 17, 115-132.

[5] Hoque, K. 2000a, 'HRM and Performance in the Hotel Industry,' Human Resource Management Journal, 10, 3, 120-136.

[6] Hoque, K. 2000b, Human Resource Management in Hotel Industry: Strategy, Innovations and Performance. London: Routledge.

[7] Ahmad, Asfaq, M. Bashir, Sultan Mabariz, 2011, How Service Quality Affects Performance of Conventional Banks in Pakistan. International Journal of Contemporary Research in Business.

[8] Zeithmal, V.A., Parasuraman, A. \& Malhotra, A. (2000). Service Quality Delivery through Websites: a Critical Review Of Extant Knowledge. Journal of the Academy of Marketing Science, 30 (4), 362-375.

[9] Lado, Agustin .A dan Mary C. Wilson, (1994) Human Resource System and Sustained Competitive Advantage a Competency Based Perspective. Academy of Management Riview 19:699-727.

[10] Mathis, Rober L \& Jackson, John H, 2005, Human Resource Management, Alih bahasa Diana Angelica, Penerbit, Salemba Empat.

[11] Pfeffer, J. (1994). Competitive Advantage through People. Boston, Massachusetts: Harvard Business School Press.

[12] Ulrich, Dave. 1997. Human Resource Champions, The Next Agenda for Adding Value and Delivering Results. Boston, Massachusetts : Havard Business School Press.

[13] Greer, Charles P, 2001. Strategic Hunan Resource Management: A General Management Approach. Second Edition, Prentice Hall Inc. New Jersey

[14] Cho, Seonghee., Woods, Robert H., Jang, SooCheong., dan Erden, Mehmet. 2006. Measuring The Impact of Human Resource Management Practices on Hospitality Firms' Performance. Hospitality Management Journal, 25, pp.262-277.

[15] Alleyne Philmore, Liz Doherty, Dion Greenidge. 2005. Human Resource Management and Performance in The Barbados Hotel Industry. Journal of Hospitality Management (2006) pp. 623-646.

[16] Guest, D.E. 1997. Human Resource Management and Industrial Relations. Journal of Management Studies, 15(5),PP503-21

[17] Chen,Chung Jen., Huang, Jing-Wen, 2009 Strategic HR and innovation performance_the mediating role of KM capacity, Journal of Business Research 62 (2009) 104-114

[18] Hsu,I-Chieh, 2008, Knowledge sharing practices as a facilitating factor for improving organizational performance through human capital: A preliminary test, Dept. of Business Administration, National Changhua University of Education, No. 1, Jin-De Road, Changhua 500, Taiwan, pp, 1316-1326. 
[19] Alavi, M., \& Leidner, D. E. (2001). Review: knowledge management and knowledge management systems: conceptual foundations and research issues. MIS Quarterly, 25(1), 107-136.

[20] Davenport, T. H., \& Prusak, L. 1998. Working knowledge: How organizations manage what they know. Boston, MA: Harvard Business School.

[21] Holsapple, C. W., \& Joshi, K. D. (2002). The evolution of knowledge management frameworks. In S. Barnes (Ed.), Knowledge management systems: Theory and practice. London: International Thomson Press.

[22] Liebowitz, J. (2000). Building organizational intelligence-A knowledge management primer. Boca Raton, FL: CRC Press.

[23] Nonaka, I., \& Takeuchi, H, 1995, The knowledge-creating company: How Japanese companies create the dynamics of innovation. Oxford: Oxford University Press.

[24] Bose, Ranjit, 2003, Knowledge Management-enabled healt care management systems: Capabilities, Infrastructure, and decision Support. Expert System with Applications, 24, 59-71

[25] Chand, Mohinder, 2010, The Impact of HRM Practices on Sercive Quality, Ccustomer Satisfaction and Performance in The Indian Hotel Industry, The Internasional Journal of Human Resource Management Vol.21,No.4, pp.551-566.

[26] Tsaur, Sheng Hshiung., Lin, Yi Chun_2004, Promoting Service Quality in Tourist Hotel. The Role Of HRM Practices and Service Behavior, Tourism Management, 25, 471-484.

[27] Chyn, Goh, Hui, Kaliannan, Maniam, 2009, Human Resoure Management Practices in Logistic Service Provider Industry: A Case Study, Interdisciplinary Journal of Contemprary research Business, Vol. 2 No. 9, pp 32-44.

[28] Orzano, A. John., Mclnerney C.R., Schaart, David., Tallia Alfred F., Crabtree, Benjamen F. 2007. Knowledge Management Model: Implications for Enhancing Quality in Health Care. Accepted September 12, 2007

[29] Su, Hwan Yann, and Lin, Yichen, 2006, Enhancing Knowledge-Based Service Quality: A Knowledge Management Perspective. The Service Industries Journal.

[30] Karl, A. K. (2003). Human resource management in the knowledge economy. The Academy of Management Executive. Vol. 17, Iss. 2, p.137-139

[31] Raich, M. (2002). HRM in the knowledge-based economy: is there an afterlife? Journal of European Industrial Training. Vol.6, Iss.7, p.269

[32] Currie G, dan Kerrin M, 2003, Human Resource Management, and Knowledge Management enhancing Knowledge Sharing in a pharmaceutical company. Int J Hum Resour Manag 2003 14(6):1027-45.

[33] Appelbaum, E.,Bailey,T.,Berg.P.and Kalleberg.A.L., 2000, Manufacturing Advantage: Why High Performance Work System Pay Off.Cornell University Press. Economy Policy Institute.

[34] Guest, D. E., 2001, Industrial Realtion and Human resource management, and Human resource Management : A Critial Text, ed J Story, Thomson Leaning, London.

[35] Woods, R.H. (1992), Managing Hospitality Human Resources, East Lansing, MI: Educational Institute of the American Hotel and Motel Association.

[36] Arthur, Jefffey.B.,1992, The Link Between Business Strategy and Industrail Relations System in American Steel Mills, Industrial and Labor Relations Review, 45(3) pp 488-506.

[37] Huselid, M.A., dan Deleney J.T. 1996, The Impact of Human Resource Management Practices on Perceptions of organization Performance Academy of Management Journal, 39(4), 949969.

[38] Huselid, M. A. 1995. The Impact of Human Resource Management Practices on Turnover, Productivity, and Corporate Financial Performance. Academy of Management Journal, 38(3), 635672.

[39] MacDuffie, J.P., 1995, Human Resource Bundles and Manufacturing Performance: Organizational Logic and Flexible Production System in The world Auto Industry. Industrial anf Labor Relation Review 48, 197-221

[40] Dyer dan Reeves, 1995, Human Resource Strategies and firm performance: What do we know and where do we need to do? International Journal of Human Resource Management 6 (3), 656-671.

[41] Ichniowski C, Show K, Prennushi (1997) The effects of Human Resource Management Practices on Pruductivity: A Study of Steel Finishing Lines. Am Econ Rev 1997 87(3):291-313.

[42] www.egain.com Knowledge Managment for Customer Service, Marer, 2012.

[43] Rachmany, H. \& Akib, H. (2002). Rekonstruksi manajemen pengetahuan. Majalah Manajemen.

[44] Skyrme, D .J. (2003) Knowledge management: making sense of an oxymoron. Stata, R., 1989. Organizational learning-the key to management innovation. Sloan Management Review, Spring.

[45] Nonaka, Ikujiro, 1991, The Knowledge Creating Compeny. Harvard Business Review, 69(6),96-104.

[46] Cronin, J. J. Jr, \& Taylor, S. A. (1992). Measurement service quality a re-examination and extension. Joumal of Marketing, 7, 55-68.

[47] Oliver, R.L. (1993). "A Conceptual Model of Service Quality and Service Satisfaction: Compatible Goals, Different Concepts." in Swartz, A.T., Bowen, D.E. and Brown, S.W. (Eds), Advances in Services Marketing Management, Vol. II, JAI Press, Greenwich, CT, pp.65-85.

[48] Zeithaml, V. A., Berry, L. L., and Parasuraman, A. 1993. Delivering quality set-vice: Balancing customer perceptions and expectations. New York: New York Free Press.

[49] CzepieI, J. A. (1990). Service encounters and service relationships: Implications for research. Journal of Business Research, 20: 1321.

[50] Boshoff, C., and Gray, B. (2004). The Relationships between Service Quality, Customer Satisfaction and Buying Intentions in the Private Hospital Industry. South African Journal of Business Management, 35(4), 27-37.

[51] Sachdev, S. B., and Verma, H. V. (2004). Relative importance of service quality. Journal of Services Research, 4(1), 93-116.

[52] Ekinci, Y. (2003). An investigation of the determinants of customer satisfaction. Tourism Analysis, 8(2), $193-196$.

[53] Kaplan Robert, S. and D.P. Norton, 1996, The Balanced Scorecard: Translating Strategy Into Action, Boston: Harverd Business School Press.

[54] Lovelock, C.H (1985), 'Developing and Managing the Customer Service Function in the Service Sector,' in The Service Encounter, eds. John A. Czepiel, Michael R. Solomon, and Carol F. Surprenant Lexington, MA: Lexington Books, pp. $265-280$.

[55] Schneider, B.,1994, 'HRM - A Service Perspective: Towards a Customer-focused HRM,' International Journal of Service Industry Management, 5, 64-76.

[56] Chand, Mohinder., and Katou, A., 2007, 'The Impact of HRM Practices of Organisational Performance in Indian Hotel Industry,' Employee Relation: An International Journal, 29, 576-594.

[57] Gilbert, G.R. (1991), 'Human Resource Management Practices Improve Quality: A Case Example of Human Resource Management Intervention in Government,' Human Resource Management, 10, 183-198.

[58] Tornow, W.W., and Wiley, J.W.,1991, 'Service Quality and Management Practices: A Look at Employee Attitudes, Customer Satisfaction, and Bottom-Line Consequences,' Human Resource Planning, 14, 105-115. 
[59] Hung, T.K., 2006, 'The Impact of Human Resource Practices on Service Performance of Taiwanese Hotel Industry: Organizational Commitment as a Mediator,' International Journal of the Information Systems for Logistics and Management, 1, $109-116$.

[60] Delery JE, Doty DH., 1996, Modes of theorizing in strategic human resource management: tests ofuniversalistic, contingency, and configurational performance predictions. Acad Manage J 1996 39(4):802-35.

[61] Wright PM, Dunford BB, Snell SA. 2001. Human resources and the resource-basedview of the firm. J Manage 2001 27(6):701-21.

[62] Collins, C.J., dan Clark KD, 2003, Strategic Human Resource Practices, Top Management Team Social Networks, and Performance The Role of Human Resource in Creating Organization Competitive Advantace, Acad Manage J 2003, $46(6) 74051$.

[63] Ruggles R., 1998, The state of the notion: knowledge management in practice. Calif Manage Rev 1998 40(3):80-9.

[64] Scarbrough, Harry, (2003), Knowledge Management, HRM and the innovation Process. The Emerald Research Register for this journal is available pp.

[65] Hayes N,Walsham G., 2000. Safe enclaves, political enclaves and knowledge working. In: Pritchard C, Hull R, Chumer H, Willmott H, editors. Managing Knowledge: Critical Investigations of Work and Learning. London: Macmillan; 2000.

[66] Mueller F. Dyerson R, (1999) Expert Humans and Expert organization? Organization Study 1999 20(2) 22556.

[67] Martinsons MG. (1997). Knowledge-Based Systems Leverage Human Resource Management Expertise. Int J Manpow 1995 16(2):17-34.

[68] Youndt, M.A., Snell S.A., Dean JW., Lepak DP., 1996, Human resource management, manufacturing strategy, and firm performance. Acad Manage J 1996 39(4): 836-66.

[69] Scarbrough Harry, Carter C., 2000, Investigating knowledge management. London: CIPD; 2000.

[70] Lave J, dan Wenger E.,1991 Situated learning: legitimate peripheral participation. Cambridge: Cambridge University Press; 1991.

[71] Peters, T, 1988 Thriving on Chaos. London: Macmillan

[72] Russell, S, (1999), Business Excellence: from outside in or inside out? Total Quality Management, 10, pp.83-92.

[73] Madhavan R, Grover R., 1998, From embedded knowledge to embodied knowledge: new product development as knowledge management. J Mark 1998 62(4): 1-12.

[74] Von Krogh G., 1998, Care in knowledge creation. Calif Manage Rev 1998 40(3): 133-53.

[75] Tannenbaum SI, Dupuree-Bruno LM., 1994, The relationships between organizational and environmental factors and the use of innovative human resource practices. Group Organ Manage 1994 19(2):171-202.

[76] Pfeffer J., 1998, Seven practices of successful organizations. Calif Manage Rev 1998 40(2):96-123.

[77] Mendelson H, Pillai RR., 1999, Information age organizations, dynamics, and performance. J Econ Behav Organ 38:253-81.

[78] Katou, A.A., and Budhwar, P. 2007, 'The Effect of Human Resource Management Policies on Organizational Performance in Greek Manufacturing Firms,' Thunderbird International Business Review, 49, 1, 1-35.

[79] Laursen K, Foss NJ. 2003. New human resource management practices, complementarities, and the impact on innovation performance. Camb J Econ 2003 27(2): 243-63.

[80] Michie J, Sheehan M., 1999, HRM practices, R\&D expenditure and innovative investment: evidence from the UK's 1990 workplace industrial relations survey (WIRS). Ind Corp Change 8(2):211-34.

[81] Damanpour F., 1991, Organizational innovation: a meta-analysis of effects of determinants and moderators. Acad Manage, 34(3):555-90.

[82] Morre, C. D. (1987). Outclass the Competition with Service Distinction, Mortgage Banking, 47 (11)

[83] Zeithmal, V.A., Parasuraman, A. \& Malhotra, A. (2000). Service quality delivery through websites: a critical review of extant knowledge, Journal of the Academy of Marketing Science, 30 (4), 362-375.

[84] Huang, Li-Su., Lai, Cheng-Po. 2010, Applying Knowledge Management in the Life Insurance Industry - Evidence from Taiwan, International Research Journal of Finance and Economics, ISSN 1450-2887 Issue 48 (2010)

[85] Liau, Pang-Lo., Chin, Wen-Chin., Tsai, Chih-Hung, 2004, An empirical study on the correlation between knowledge management capability and competitiveness in Taiwan's Industries, Technovation 24 (2004) 971-977

[86] Zheng, Wie, Baiyin Yang \& Gary N. McLean, 2009, Linking Organizational Culture, Strukcture, Strategy, and Organizational effectiveness, Mediating role of Knowledge Management. Journal of Bussiness Research,06836, pp.1-11.

[87] Liao, Shu-Hsien \& Chi-Chuan Wu, 2010, System Perspective of Knowledge Management, Organization Leaning, and Organizational innovation.Expert System with Application,37,1096-1103.

[88] Arthur, Jefrrey B. 1994. Effect of Human Resources System on Manufacturing Performance and Turnover. Academy of Management Journal, June, p.670-687

[89] Ulrich,D.,Halbrook,R., Meder,D., Stuchlik,M., \& Thorpe, S., (1991) Empoyee and Customer attachments, Synergies for Competitive advantege. Human Resource Planning, 14 (2), 89104. 